\title{
The effectiveness of task-based language teaching on the writing skill: a systematic research synthesis
}

\section{La efectividad de la enseñanza de idiomas basada en tareas en la habilidad de escritura: una síntesis de investigación sistemática}

1 Alberto Medina Fernández

iD https://orcid.org/0000-0002-4291-720X Pontificia Universidad Católica del Ecuador - Sede Ambato: Ambato, Tungurahua, Ecuador, Maestría en Pedagogía del Inglés como Lengua Extranjera, Ambato, Ecuador alberto.medina.f@pucesa.edu.ec

2 Paola Vanessa Navarrete Cuesta

https://orcid.org/0000-0002-3354-9580 Pontificia Universidad Católica del Ecuador - Sede Ambato: Ambato, Tungurahua, Ecuador,Docente Titular auxiliar, Departamento de Lenguas y Lingüística, Riobamba, Ecuador pnavarrete@pucesa.edu.ec

Artículo de Investigación Científica y Tecnológica Enviado: 03/11/2021

Revisado: $20 / 11 / 2021$

Aceptado: $13 / 12 / 2021$

Publicado:05/01/2022

DOI: https://doi.org/10.33262/cienciadigital.v6i1.1953

Navarrete Cuesta, P. V., \& Fernández, A. M. (2022). The effectiveness of task-based language teaching on the writing skill: a systematic research synthesis. Ciencia Digital, 6(1), 27-46. https://doi.org/10.33262/cienciadigital.v6i1.1953

CIENCIA DIGITAL, es una Revista multidisciplinaria, Trimestral, que se publicará en soporte electrónico tiene como misión contribuir a la formación de profesionales competentes con visión humanística y crítica que sean capaces de exponer sus resultados investigativos y científicos en la misma medida que se promueva mediante su intervención cambios positivos en la sociedad. https://cienciadigital.org

La revista es editada por la Editorial Ciencia Digital (Editorial de prestigio registrada en la Cámara Ecuatoriana de Libro con No de Afiliación 663) www.celibro.org.ec

Esta revista está protegida bajo una licencia Creative Commons AttributionNonCommercialNoDerivatives 4.0 International. Copia de la licencia: http://creativecommons.org/licenses/by-nc-nd/4.0/. 
Palabras

claves: TBLT, planificación de tareas, complejidad de tareas, producción de escritura L2.

\section{Keywords: \\ TBLT, task planning, task complexity, L2 writing production}

\section{Resumen}

Introducción. Esta síntesis de investigación sistemática investigó la efectividad de las intervenciones de enseñanza de idiomas basadas en tareas en el rendimiento de escritura L2 de estudiantes de nivel intermedio. Objetivo. El objetivo principal fue determinar los efectos de las manipulaciones de variables independientes de la enseñanza del lenguaje basada en tareas sobre diferentes modos de escritura medidos de manera integral y mediante constructos CALF. Metodología. La integración de datos cualitativos y cuantitativos se llevó a cabo mediante una búsqueda bibliográfica sistemática y la recuperación de artículos publicados desde 2010 hasta septiembre de 2011. Las características sustantivas y metodológicas de los estudios fueron codificadas y comparadas para la identificación de prácticas y tendencias de uso común dentro de la Enseñanza de idiomas basada en tareas y dominio de investigación de escritura L2. Resultados. Los resultados indican 3 tipos principales de intervenciones basadas en tareas: el marco TBLT, las manipulaciones de la complejidad de la tarea y las condiciones de planificación de la tarea han prevalecido como tratamientos. Los tratamientos de complejidad de tareas han tenido efectos beneficiosos en las medidas de fluidez y complejidad léxica, mientras que la planificación estratégica y el tiempo de planificación también favorecieron la fluidez en la escritura L2. A su vez, los tratamientos de lecciones del marco TBLT produjeron grandes efectos medidos como d de Cohen. Conclusión. A pesar de la amplia variedad de condiciones de tratamiento y medidas de resultado para diferentes modos de escritura L2, se brinda apoyo a la importancia de la gestión de etapas del ciclo previo a la tarea de TBLT para estudiantes de nivel intermedio.

\section{Abstract}

Introduction. This systematic research synthesis investigated the effectiveness of Task-based language teaching interventions on L2 writing performance of intermediate level students. Objective. The main aim was to determine the effects of independent variable manipulations of task-based language teaching on different modes of writing measured holistically and by means of CALF constructs. Methodology. The integration of qualitative and quantitative data was carried out by means of a systematic literature search and retrieval of published articles from 2010 until September 2011. 


\begin{abstract}
Substantive and methodological features of the studies were coded and compared for the identification of commonly used practices and trends within the Task-based language teaching and L2 writing research domain. Results. The results indicate 3 major types of task-based interventions: TBLT framework, task complexity manipulations and task planning conditions have prevailed as treatments. Task complexity treatments have had beneficial effects on measures of fluency and lexical complexity while strategic planning and planning time also favored fluency in L2 writing. In turn, TBLT framework lesson treatments yielded large effects measured as Cohen's d. Conclusion. In spite of the wide variety of treatment conditions and outcome measures for different modes of L2 writing, support is given to the importance of the pre-task cycle stage management of TBLT for intermediate level learners.
\end{abstract}

\title{
Introduction
}

In recent years there has prevailed an emphasis on the effects of Task-based language teaching frameworks in the development of the productive skills. However, applied linguistics researchers have traditionally prioritized oral skills rather than writing skills in TBLT research interventions. Within a TBLT framework, real world tasks are converted into pedagogical tasks (Nunan, 2004). In turn, pedagogical tasks may have a rehearsal rationale or an activation rationale. That is, they can be aimed towards practicing actual situations in the outside world, or they could, in turn, serve as a vehicle for the activation of language skills and communicative functions previously rehearsed. The purposes of tasks have traditionally been treated through the framework proposed by Ellis (2003): pre-task, during task and post-task.

In regard to TBLT treatments for writing skills, research to date has been concerned with manipulations of variables such as cognitive task complexity, task planning, planning time, pre-task phase, task sequencing and task repetition. According to Robinson (2001), it was argued that the task complexity variable was the result of the attentional memory and reasoning demands imposed by the structure of the task on the language learner. Thus, key features have been identified as resource-directing tasks (more familiar, less demanding) and resource-depleting tasks (more demanding and including use of prior knowledge). The simpler and more familiar task is completed faster than the more complex task. As Robinson (2001) states, these dimensions can be manipulated during the task design process to allow for an optimal allocation of linguistic resources that could satisfy the linguistic demands of a task. 
In a previous synthesis by Johnson (2017), studies that operationalized task complexity as dependent variable and CALF measures as dependent variables, it was suggested by the author that task complexity may promote the learners' attention to the formulation and monitoring systems of the writing process.

Task variables around the notion of planning and time management have also been thoroughly investigated in the TBLT research domain. The impact of variables such as pre-task, task planning and task types on the dimensions of L2 performance has been well-documented in the research literature to date. It has been evidenced by Foster \& Skehan (1996) study that pre-task activities influence the ways in which the tasks are to be carried out. In this work, planning time and planning strategies had a major impact on the tradeoff effect of complexity, accuracy and fluency. By means of three task types: Personal information exchange, Narrative task and Decision-making task, it became clear that each of these produced varied results in terms of complexity, accuracy and fluency measures. To date, Johnson (2017), in a synthesis involving effects of task-based language teaching on L2 writing skill instruction has reviewed solely task complexity and CALF measures through a quantitative approach. Therefore, there persists the need of reviewing the effectiveness of task-based language teaching interventions and task manipulations that involve other relevant independent variables of incidence on L2 writing performance and modes of writing by means of the integration of qualitative and quantitative data.

To elucidate on the impact of the independent variables on L2 written production this research synthesis aims to appraise: (a) the effects of a TBLT framework and manipulation of pedagogical tasks' aspects on L2 written production, (b) the substantive and methodological features of TBLT variables on language performance CALF dimensions, and (c) the ways in which writing skills' performance has been operationalized in the reviewed studies.

As stated by Norris and Ortega (2006), research synthesis aims at inspecting the actual evidence that may be compiled across studies within a research domain and that puts forth the substantive and methodological features that may be influencing the studies' results.

\section{Theoretical Framework}

\section{Writing skills and dimensions of L2 written production}

The development of oral skills has been prioritized over writing skills and written production in Second language and foreign language acquisition research. Reasons for this, as stated by Cumming (2013), have been that writing is primarily developed through education and that it includes mechanical aspects such as spelling, style, intentionality, 
among others. In contrast to spoken production, for written output, writers need to acquire resources and skills that allow them to think, plan, edit and revise written texts.

Without a doubt, research into writing comprises various aspects of SLA as well as foreign language research. For the purpose of this study, the development of writing will be analyzed in instructional settings that highlight the occurrence of: 1) dependent variables such as expository writing, descriptive texts, essay writing skills, narrative writing skills, collaborative writing, and 2) dimensions of language performance identified as CALF measures (syntactic complexity, accuracy, lexical complexity and fluency), including holistic measures of the modes of writing.

\section{Complexity}

As defined by Ellis (2003), complexity is characterized as the extent to which the language produced during performing a task is varied and elaborate. As a dependent variable in oral or written production investigations, complexity is often linked with fluency and accuracy. For the purposes of this synthesis' research domain, the notion of complexity is divided into syntactic complexity, lexical complexity and cognitive complexity.

Syntactic complexity, in written language research, has been usually associated with subordination. In turn, it has been found that metrics of syntactic complexity are different in both spoken and written language since written genres serve a different function from those of speaking (Biber \& Conrad, 2009).

Lexical complexity in L2 writing performance research has been traditionally divided into lexical diversity (measured as the ratio of unique words to total number of words), lexical density (the proportion of content words total of words), and lexical sophistication (typically measured as the use of a wide range of low-frequency vocabulary) (Johnson, 2017).

\section{Accuracy}

In a broad sense, accuracy must be interpreted as synonymous with appropriateness and acceptability (Housen et al., 2012). In written performance, accuracy has been previously operationalized by measuring the occurrence of lexical errors per 100 words, and by total number of errors per T-units (main clause and subordinate clause) (Kuiken \& Vedder, 2007). In any case, the level of accuracy can best be measured by means of syntactic units such as clauses, T-units and AS-units which can be classified as error-free or not errorfree in a more reliable manner. 


\section{Fluency}

Fluency has been understood as the effortless accessibility and production of language knowledge that the user or learner possesses. However, this wide concept has been usually applied to speaking treatments. In written production, fluency has frequently been operationalized through quantitative-process factors that include measures of syllables per minute or by means of process-based indicators represented by length of proposed text, output chunk size and pausing (Dormer, 2017).

\section{Research questions}

Due to the growing interest in ISLA research to investigate the effects of Task-based language teaching on the productive skills, and its viability for application in classroom settings, this research synthesis aims at scoping out the existing research field of the development of writing in a myriad of contexts where TBLT has been researched. Considering the state-of-the-art of the existing published empirical research literature, the authors propose the following research questions:

Research question 1: What kind of task-based interventions have been more frequently chosen by researchers for writing skills' treatments?

Research question 2: What is the relationship among the CALF dimensions of complexity, accuracy, lexis and fluency in written production, and which dependent measures have been preferred by researchers to investigate these constructs?

Research question 3: To what extent do reviewed studies show that task-based language teaching is effective in developing writing skills and modes of writing in classroom contexts?

\section{Methodology}

To assess the effectiveness of TBLT interventions on writing development, the current study adopted a synthesis methodology to grasp the state of knowledge accumulated across empirical studies. It sets out to provide an overview of the impact of task variables used on different types of writing skills. The methodological approach adopted has been mixed-method systematic review in order to include data extracted from published quantitative, qualitative and mixed-method primary research articles retrieved (Heyvaert et al., 2011).

\section{Search keywords}

The first step taken in the search process was to define the proper search keywords that could yield results for the intended objectives and research questions previously proposed. The following set of keywords and term combinations were used to retrieve the 
studies by means of the search and retrieval strategies (a) combination of keywords, and (b) keywords in isolation:

(TASK-BASED LANGUAGE TEACHING / PEDAGOGICAL TASKS/ TASK PLANNING/ WRITING TASKS / WRITING SKILLS /COLLABORATIVE WRITING/ WRITTEN OUTPUT / L2 WRITING PRODUCTION)

Terms used in combinations:

[“TASK-BASED LANGUAGE TEACHING"] + [“COMMUNICATIVE TASKS"] + ["PEDAGOGICAL TASKS"] + [“TASK PLANNING"] + [“PRE-TASK"] + [“TASK COMPLEXITY"] + [“L2 WRITTEN PRODUCTION"]

Studies were systematically searched and identified through the following databases: (a) Eric, (b) Science Direct, (c) Microsoft Academic, and (d) Google Scholar. Subsequent electronic searches were conducted on 12 peer-review journals in this field: (Advances in Language and Literary Studies, Applied Linguistics, ELT JOURNAL, English Language Teaching, International Journal of Applied Linguistics, Journal of English as an international Language, Journal of Second Language Writing, Language teaching research, Modern Language Learning, Sage, TESOL Quarterly, and the language learning Journal)

\section{Criteria for study selection}

The initial electronic query resulting from the keyword combinations used in the databases and selected journals led to a pool of 68 articles. From this result, abstracts and titles were briefly analyzed by the authors considering the following criteria for inclusion:

1) The studies had a presence of Task-based language teaching interventions as independent variables on extended pieces of writing, writing skills, or written performance as dependent variables.

2) The participants reported in the study were L 2 writers in foreign language or second language instructional contexts and studies were published in international peerreviewed journals.

3) All selected studies were from an eleven-year span period from September 2010 to September 2021 according to an increase in attention to investigating writing performance and skills within the TBLT research domain.

Inclusion and exclusion process:

After applying these criteria to our dataset, the following phases ensued for the elimination process of studies that did not match the synthesis objectives and selection requirements. Further iterative analyses of documents retrieved allowed the researchers to exclude articles from the main study through these processes depicted in Figure 1: 
Phase 1: elimination of papers due to tittle relevance and duplication.

Phase 2: examination of abstracts according to selection criteria and exclusion of nonempirical studies.

Phase 3: analysis of full article according to their direction, research object, method section examination and overall quality.

Figure 1

Process of literature selection

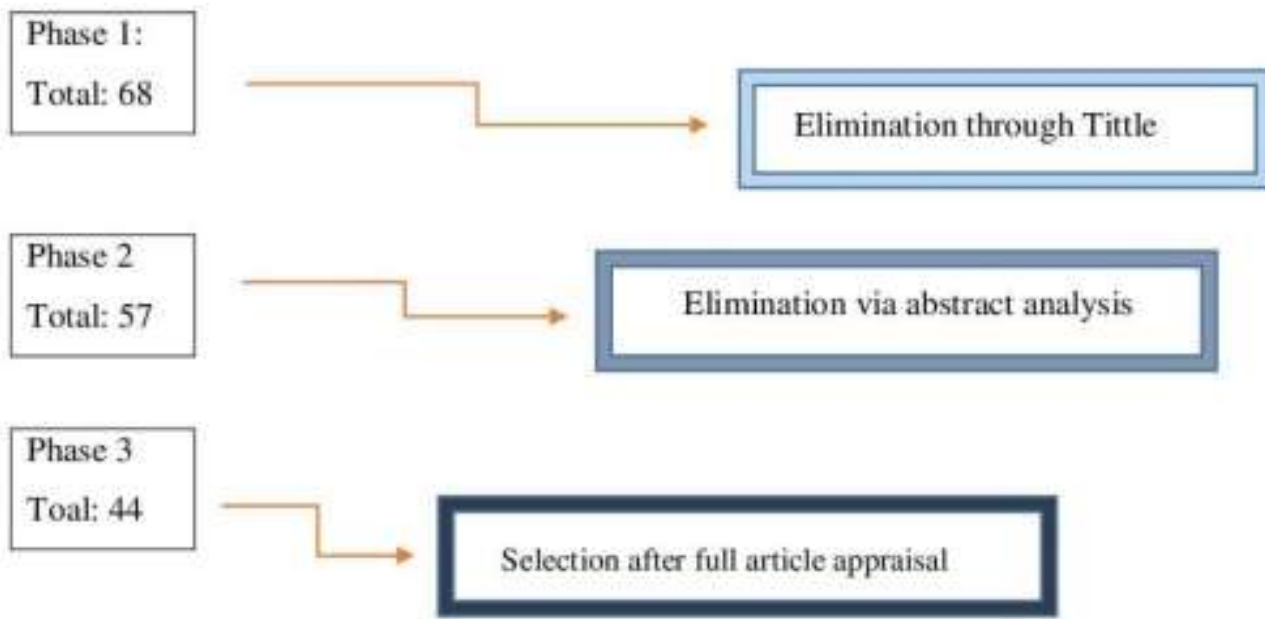

Source: 3-steps process of literature elimination. Developed by: The authors

Process of data collection and coding of study features

The nature of this current synthesis allowed for the inclusion of studies having varied research designs and methods. Consequently, study reports were coded for substantive features, methodological variables, moderator variables, and general characteristics that would allow us to synthesize the information in a quali-quantitative manner. Because of the wide variety of research designs, independent variables and outcome measures described in the 44 included studies, we proposed the coding generic categories depicted in table 1 .

Table 1

Coded information from reports

\begin{tabular}{cc}
\hline Substantive and Methodological Features & Classification \\
\hline General Characteristics: & \\
\hline $\begin{array}{c}\text { Institution Type } \\
\text { Country }\end{array}$ & Elementary, High school, University, Institute \\
The country where the study took place
\end{tabular}


Table 1

Coded information from reports (continued)

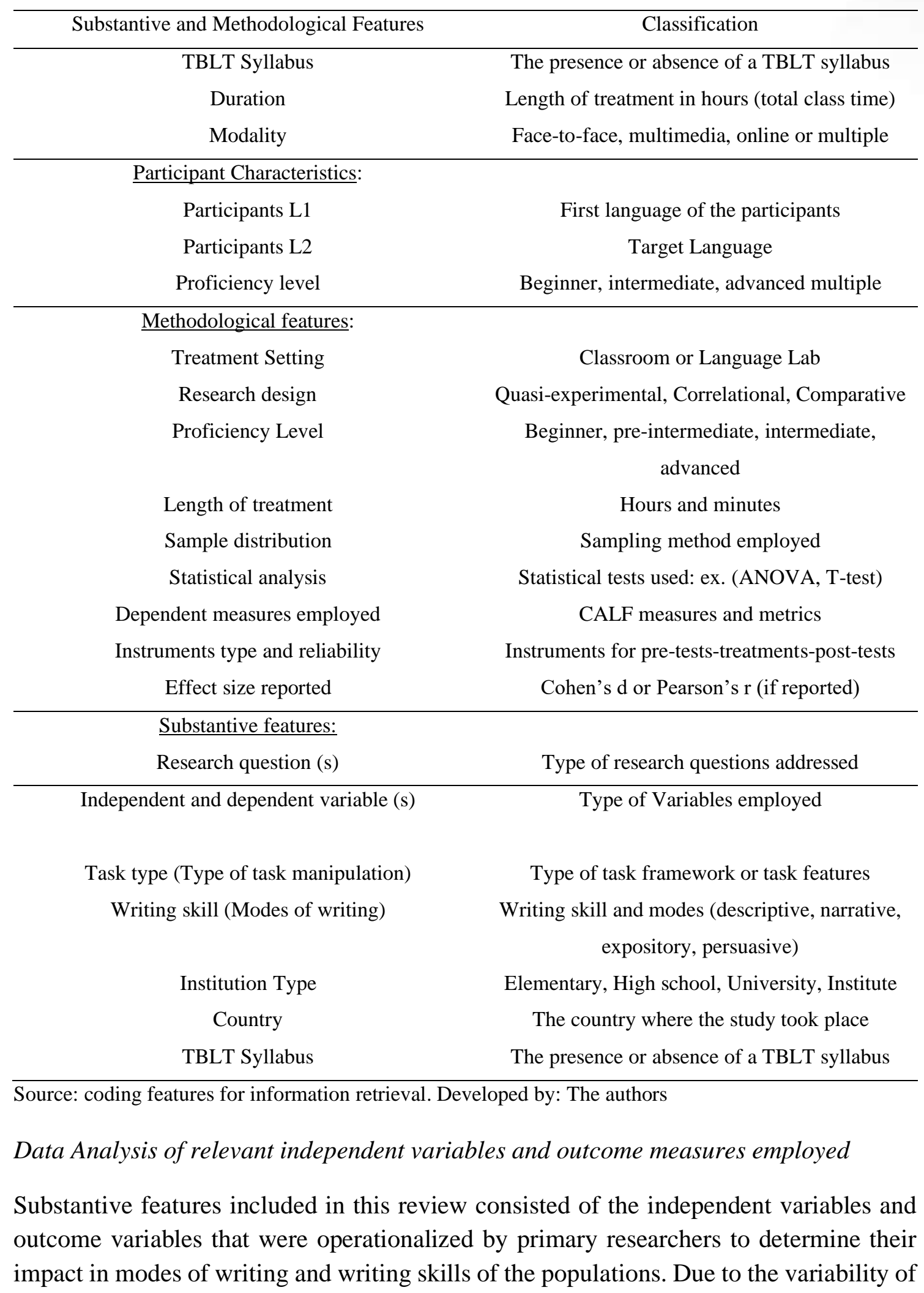




\section{www.cienciadigital.org}

research designs, independent variables and outcome measures reported, the coding of specific features was carried out by classifying them into generic types in table 2 . Outcome measures were coded as two generic categories that comprised:

1-CALF metrics for syntactic complexity, lexical accuracy, lexical complexity, grammatical accuracy, fluency, compositional fluency and cohesion.

2- Scales or writing rubrics' results for the different modes of writing when reported.

\section{Table 2}

\section{Type of Intervention Employed}

\begin{tabular}{cc}
\hline Intervention Type & No. of Studies \\
\hline TBLT Framework & 18 \\
Task Complexity & 11 \\
Task Planning & 9 \\
Pre-task Planning & 1 \\
Planning Time & 1 \\
Task Structure & 1 \\
Task Repetition & 1 \\
Task Sequencing & 1 \\
SSARC Model & 1 \\
\hline
\end{tabular}

Total $(\mathrm{N}=44)$

Source: Task treatments as independent variables in the reviewed studies. Developed by: The authors

\section{Results}

Characterization of the reviewed literature included in the research synthesis:

In this section the features pertaining to the body of literature of task-based interventional studies on L2 writing performance is presented. We account for the main coded characteristics of: (a) population and settings, (b) research designs, (c) statistical analyses, (d) Independent variables and (e) outcome measures and metrics employed for L2 writing production.

Publications. The studies reviewed in the synthesis came from peer-review journals $(n=23)$ and international conferences $(n=2)$ and were published from 2010 to September 
2021. Although unpublished doctoral and master theses were also retrieved, they were not included in the synthesis.

Participants and setting characteristics. Out of the total of participants in the reviewed studies only $11,36 \%$ constituted high school students between the ages of 13 to 17 . The rest of participants, $(88,64 \%)$, were university students or adult learners at language institutes. First language of participants was Arabic, Chinese, Korean, Turkish, Spanish and English. Target languages in the studies appeared in order of highest frequency to lowest as: English, German, French and Spanish. As for settings, many studies $(n=43)$ were held in a foreign language classroom context, and one $(n=1)$ took place in a second language environment.

Research designs. A $72 \%$ of all studies employed quasi-experimental designs with experimental and control/comparison groups. The rest of studies were either correlational or pre-experimental within-subject designs, and two action research studies were also included.

Statistical analyses. Within this research domain, it prevails the use of ANOVA tests $(33,3 \%)$ and, or descriptive statistics $(28,5 \%)$ combined with independent sample t-tests $(23,8 \%)$ and MANOVA $(14,2 \%)$ out of the total of 42 studies that employed statistical analyses.

Independent variables and task manipulations. Task-based interventions treatments for writing performance were classified here into three main different groups: TBLT holistic frameworks, task complexity manipulations and task planning strategies. A significant number of studies $(n=18)$ operationalized a TBLT framework as pre-task, during task and post-task cycles. Task complexity, in turn, appeared as manipulations of task structure being split into two or more levels of complexity. Variables used included contrasts between a complex task and a simple task, or as an increase in the level of complexity. Pre-task and task planning interventions were treated by comparing manipulations of time and 2 or 3 conditions such as strategic planning, online planning and collaborative planning. Other variables included task repetition $(n=1)$, and task sequencing via SSARC (stabilize, simplify, automatize, reconstruct, and complexify).

\section{Outcome measures}

The 44 studies included in the synthesis contained many measures and metrics to assess L2 writing performance using a holistic approach and CALF dimensions. General measures and specific measures were both employed to appraise L2 writing production. Holistic ratings have been used through analysis of scoring rubrics of content, organization, vocabulary, language use (grammar) and mechanics. On the other hand, CALF constructs have been operationalized as mean length of T-units (main clause and 
any subordinate structures) for syntactic complexity. Accuracy was regularly measured as the proportion of error-free T-units (dominant clause and dependent clauses), and calculations of totals of number of errors per 100 words. Lexical complexity measures comprised metrics for lexical diversity and lexical sophistication among which some studies used MTLD (measures of textual lexical diversity). Fluency measures in most studies were analyzed by means of the average number of words per T-unit, syllables per minute or the number of words per minute in 30- or 25-minutes' intervals.

\section{Main effects of task complexity on L2 writing}

Many studies reviewed that used manipulations of task complexity as independent variable, have, as theoretical basis, two views that affect the number of attentional resources given to the production of the L2 writing process. On the one hand there is Skehan (1998) limited attentional capacity model which posits a conflict in learner's attention to both content and form. On the other hand, the cognition hypothesis which indicates that attentional resources to CAF constructs does not necessarily compete, but rather benefit learners L2 interlanguage as different task complexity dimensions are manipulated. These aforementioned models have been more extensively utilized in TBLT oral production research, and not so often in L2 writing production. Nonetheless, reviewed quantitative studies have used their theories to investigate the effectiveness of task complexity treatments on CALF dimensions in L2 writing. The analysis-synthesis process of the studies revealed that manipulations of task complexity conditions produced gains in fluency and lexical complexity, but not so much for accuracy. When provided with more task structures or language support, in the conditions of treatments, learners produced less complex language and, in turn, substantial effects in accurate production were evidenced (Adams et al., 2015). As can be seen in Table 3, many treatments and conditions for independent variables involved the comparison of groups with tasks that increased the complexity level, or resource dispersing features, in their execution. In most instances, measures of L2 writing output indicated an alignment with either the limited attention capacity model (Skehan, 1998) or Robinson's (2001) cognition hypothesis.

\section{Table 3}

\section{Task complexity treatments and L2 writing constructs measured}

\begin{tabular}{lll}
\hline \multicolumn{1}{c}{ Study } & \multicolumn{1}{c}{ Task Treatments } & \multicolumn{1}{c}{ Writing Production Measures } \\
\hline Abrahams (2019) & Integrated writing & $\begin{array}{l}\text { syntactic complexity, grammar, } \\
\text { lexis, choice }\end{array}$ \\
Adams et al. (2015) & Task structure (Low vs. High) & $\begin{array}{l}\text { complexity and accuracy } \\
\text { Frear \& Bitchener (2015) }\end{array}$ \\
$\begin{array}{l}\text { (Low, medium, high } \\
\text { complexity) }\end{array}$ & $\begin{array}{l}\text { syntactic complexity, } \\
\text { subordination, lexical variety }\end{array}$ \\
\hline
\end{tabular}


Table 3

Task complexity treatments and L2 writing constructs measured (continued)

\begin{tabular}{|c|c|c|}
\hline Study & Task Treatments & Writing Production Measures \\
\hline Golpavar \& Rachidi (2021) & $\begin{array}{l}\text { Integrated writing: (Simple \& } \\
\text { Complex task) }\end{array}$ & summary \& synthesis writing \\
\hline Hsu, H. (2020) & Simple and Complex tasks & collaborative writing interaction \\
\hline Kormos (2011) & $\begin{array}{l}\text { Description and Narration tasks } \\
\text { (low vs. high cognitive load) }\end{array}$ & $\begin{array}{l}\text { lexical \& syntactic complexity } \\
\text { accuracy, cohesion \& } \\
\text { connectives }\end{array}$ \\
\hline Lee (2020) & Task closure & $\begin{array}{l}\text { syntactic complexity, lexical } \\
\text { variety, }\end{array}$ \\
\hline Shajeri \& Izadpanah (2016) & Simple vs. Complex task & $\begin{array}{l}\text { accuracy, fluency, lexical \& } \\
\text { structural complexity }\end{array}$ \\
\hline Vasylets et al. (2017) & $\begin{array}{l}\text { Simple vs. Complex } \\
\text { argumentative task }\end{array}$ & $\begin{array}{l}\text { complexity, accuracy \& time on } \\
\text { task }\end{array}$ \\
\hline Zhan et al. (2021) & $\begin{array}{l}\text { Narrative vs. Argumentative } \\
\text { task }\end{array}$ & $\begin{array}{l}\text { lexical complexity, accuracy, } \\
\text { fluency }\end{array}$ \\
\hline Zhan \& Ong (2010) & $\begin{array}{l}\text { Planning time in (pre-task vs. } \\
\text { free writing) }\end{array}$ & fluency \& lexical complexity \\
\hline
\end{tabular}

Source: Task complexity manipulation studies. Developed by: The authors

\section{Effects of task planning on writing performance}

Task planning interventions in the reviewed studies consists of pre-task planning, strategic planning and online planning within a TBLT framework. In pre-task planning learners rehearsed the task before actual performance, while in strategic planning, a plan of the content and language relevant to the task was carried out (Tabari, 2021).

Planning effects on measures of lexical complexity and syntactic complexity, accuracy and fluency have been varied across some studies. However, it has been found that increasing the amount of planning time yields greater gains for fluency. In turn, the provision of a strategic planning condition improves all CAF dimensions and in particular lexical complexity. Pre-task planning has had no effect on lexical and grammatical complexity and only small effects on fluency.

Effectiveness of a task-based language teaching frameworks and other variables on writing skills and modes

In 18 reports of our corpus of studies TBLT interventions were operationalized as TBLT framework as a holistic intervention in lessons. In general, the quantitative and quantitative analyses in these studies $(n=16)$ point towards gains in the effects of experimental groups that employed holistic TBLT interventions in quasi-experimental 
research designs. Only 2 studies employed an action research methodology. Writing skills and modes in many of these studies were measured as narrative texts, academic writing, argumentative text, descriptive texts and scientific writing. Only one study used CALF constructs as measures of L2 writing output, the rest of quantitative or mixed-method studies utilized writing rubrics (content, organization, vocabulary, language use \& sentence dynamics) to measure writing performance. In some cases, means of TBLT experimental groups were greater in more than $5 \%$. however, in one study of Marashi \& Mirghafari (2019), where the control group was operationalized as CBI (content-based instruction), the means of the TBLT experimental group was lower than the CBI control group. Mixed method studies evidenced improvements in the appraisal of other variables such as motivation, attitude and writing critically. Table 4 shows the studies that could be analyzed for effect sizes. Cohen's d effects were calculated whenever studies did not report any effect sizes. The formula used was: Cohen's $\underline{d=(M 2-M 1)}$ / SDpooled in which $\mathrm{M} 2=$ means of experimental group posttest and $\mathrm{M} 1=$ means of control group posttest for studies involving t-tests for means divided by the pooled standard deviations of the two groups (Cohen, 1988).

Table 4

Cohen's d for between-groups quasi-experimental (experimental-control group designs)

\begin{tabular}{|c|c|c|c|c|c|}
\hline Study & Measure & Stat. Test & Exp. & Ctrl. & $\mathrm{d}$ \\
\hline Dirgeyasa (2018) & $\begin{array}{l}\text { Academic writing } \\
\text { rubric }\end{array}$ & T-test & 1.867 & 0.82 & 1.9 \\
\hline $\begin{array}{l}\text { Kafipour et al. } \\
\text { (2018) }\end{array}$ & $\begin{array}{l}\text { Analytic writing } \\
\text { rubric }\end{array}$ & T-test & 12.64 & 9.01 & 3.2 \\
\hline Parvizi et al. (2016) & $\begin{array}{l}\text { Expository writing } \\
\text { rubric }\end{array}$ & Paired t-test & - & - & 1.06 \\
\hline $\begin{array}{l}\text { Rajabi \& Hashemian } \\
(2015)\end{array}$ & $\begin{array}{l}\text { Resumptive } \\
\text { pronouns }\end{array}$ & One-way ANOVA & 10.4 & 4.8 & 1.79 \\
\hline Sari et al. (2020) & Writing rubric & Descriptive Statistics & 64.8 & 55.03 & 0.94 \\
\hline Sari et al. (2018) & Writing rubric & $\begin{array}{l}\text { Descriptive Statistics } \\
\text { (One-way ANOVA) }\end{array}$ & 82.47 & 76.84 & 1.2 \\
\hline
\end{tabular}

Note: Stat. test =prevailing statistical test in the study, Exp.= mean of experimental group, Ctrl. $=$ mean of control group. Source: Calculation of Cohen's d effect sizes for experimental-control group designs for TBLT framework interventional studies. Developed by: The authors

Due to lack of standard deviations data and the varying amount of outcome measures and research questions employed in these studies, it was not advisable to carry out a metaanalysis of results that could be generalized to the general population. Nonetheless, as can be seen in Table 4 all quasi-experimental between-group studies obtained a large effect size in between-groups comparisons but considering the small sample sizes of the 
studies it can be said that further studies are needed for an assessment of their metaanalytic value.

\section{Discussion}

Research question 1: What kind of task-based interventions have been more frequently chosen by researchers for writing skills' treatments?

The first question posed at the beginning of these synthesis is split into three main blocks of intervention that have been used to measure the effect of TBLT on writing performance. The type of interventional treatment preferred by researchers has been TBLT frameworks based around a structure of pre-task, during-task and post-task in writing lessons. Secondly, there is evidence of pre-task linked to task complexity manipulations by setting different conditions along resource-directing and resource dispersing resources. In this case, studies have generally compared the effects of simple tasks with complex tasks on syntactic and lexical complexity, accuracy and fluency. Lastly, there is the preference of task planning manipulations which evidenced gains for strategic planning and time allotment. The more time learners spent on planning seemed to favor fluency gains while attention to both content and language before the actual execution of the task favored all measures of CAF constructs.

Research question 2: What is the relationship among the CALF dimensions of complexity, accuracy, lexis and fluency in written production, and which dependent measures have been preferred by researchers to investigate these constructs?

Task complexity and task planning studies revealed varied results that both supported and refuted Skehan (1998) Trade-off hypothesis, and Robinson (2001) Cognition hypothesis. For task complexity studies, findings suggest that increases in the complexity level of tasks have a positive effect on fluency while a negative one for accuracy in line with the Trade-off hypothesis. Nonetheless, a few studies lent support to the cognition hypothesis since all CALF dimensions improved because of task complexity manipulations, regarding the pre-task phase. In turn, task planning studies showed that planning time in pre-task benefits fluency. Collaborative planning and strategic planning favor lexical and syntactic complexity. Accuracy is only enhanced with the inclusion of strategic planning and not with other task planning manipulations.

In these studies, CALF measures used were syntactic complexity (mean length of T-units) and (number of subordinate clauses). Accuracy was often operationalized as lexical

accuracy (spelling errors, plural forms) and grammatical accuracy with the inclusion of metrics for number of error-free T-units, and or, number of connectors. Fluency measures included: (number of syllables per minute), compositional fluency and cohesion. 
Research question 3: To what extent do reviewed studies show that task-based language teaching is effective in developing writing skills and modes of writing in classroom contexts?

Considering posttest results of many studies employing a TBLT holistic framework for writing skills development, it can be stated that there has persisted a statistically significant difference when compared to other traditional methods such as PPP (presentation-practice-production) or even communicative approach based around communicative functions. One aspect that contributed to these large effects has been the collaboration among learners and the revision that is typical of TBLT lesson frameworks. However, we would like to point out that these effects have been more relevant for the case of narrative and descriptive writings and essays in between-groups designs.

There is also the presence of other variables such as motivation and attitudes which have been incorporated in a quali-quantitative manner through questionnaires and surveys. For the latter, results have made clear the fact that a TBLT framework provides cooperation and communication among learners and consequently they feel more involved and motivated to perform the writing tasks. Ultimately, even though the reviewed studies revealed some statistically large effects of Cohen's d, limitations such as small sample sizes or short treatment time impede the generalization of results to learners of all cultures and backgrounds.

\section{Conclusions}

- This research synthesis sought to examine how TBLT investigations and interventions affected L2 writing performance in different modes. CALF measures investigated point to overall improvements for fluency and complexity across most studies. The use of 2 main components: 1) simple vs. complex task, 2) pre-task planning time and language support manipulations, indicate tradeoffs among complexity, accuracy and fluency. In any case, reviewed studies evidenced that when provided with more support in terms of time or language in a pre-task cycle, intermediate level learners increase the linguistic output of their L2 writing.

- Due to the varying methodological features and statistical analyses in this domain, it becomes hard to generalize all results in terms of overall treatment effects. This is evidenced by the preference of ANOVA tests that have measured different levels and conditions for task complexity and task planning interventions. Comparisons between collaborative planning conditions with individual planning and no planning favored gains in almost all CALF measures for the collaborative planning condition.

- Studies employing TBLT framework as a holistic intervention demonstrate large effects measured as Cohen's d. In any case, one of the limitations of the current synthesis is that there was insufficient information to average the effect sizes 
across studies that compared TBLT with other traditional method in L2 writing classes. On the other hand, samples have been for the most part small which hinders a valid generalization of the results to a broader context. Lastly, future syntheses could include other variables such as motivation and attitude which would give a better understanding of the impact of writing tasks in L2 writing development for intermediate level adult students in a university setting.

\section{Bibliographic references}

Abrahams, Z. (2019). The effects of integrated writing on linguistic complexity in L2 writing and task-complexity. System, 81(2019), 110-121. https://doi.org/10.1016/j.system.2019.01.009

Adams, R., Alwi, M. N. \& Newton, J. (2015). Task complexity effects on the complexity and accuracy of writing via text chat. Journal of Second Language Writing 29(2015), 64-81. http://dx.doi.org/10.1016/j.jslw.2015.06.002

Biber, D., Conrad. S., (2009). Register, genre and style. Cambridge University Press.

Cohen, J. (1988). Statistical power analysis for the behavioral sciences ( $2^{\text {nd }}$ ed.). Hillsdale, NJ: Erlbaum.

Cumming, A. (2013). Writing development in second language acquisition. In C. A. Chappelle (Eds.), The encyclopedia of applied linguistics. Blackwell Publishing Ltd.

Dirgeyasa, I. (2018). The effect of task-based language teaching (TBLT) on tertiary ESOL learners' academic writing achievement. Journal of Education and Learning 12 (1), 97-104. http://doi.org/10.11591/edulearn.v12i1.7429

Dormer, R. (2017). 'Fluency' in L2 writing: a literature review. Kwansei Gakuin University Humanities Review, 21, 275-284.

Ellis, R. (2003). Task-based language learning and teaching. Oxford University Press.

Foster, P., \& Skehan, P. (1996). The influence of planning and task type on second language performance. Studies in Second Language Acquisition, 18, 299-323.

Frear, M. \& Bitchener, J. (2015). The effects of cognitive task complexity on writing complexity. Journal of Second Language Writing 30(2015), 45-47. http://dx.doi.org/10.1016/j.jslw.2015.08.009 
Golpavar, S. \& Rashidi, F. (2021). The effect of task complexity on integrated writing performance: The case of multiple-text source-based writing. System 99 (2021),102524. https://doi.org/10.1016/j.system.2021.102524

Heyvaert, M., Maes, B., Onghena, P. (2011). Mixed methods research synthesis: definition, framework, and potential. Springer Science + Business Media B.V. 2011. https://doi.org/10.1007/s11135-011-9538-6

Housen, A., Kuiken, F. \& Vedder, I. (2012). Dimensions of L2 performance and proficiency. John Benjamins Publishing Company.

Hsu, H. (2020). The impact of task complexity on patterns of interaction during webbased asynchronous collaborative writing tasks. System 93 (2020), 102328. https://doi.org/10.1016/j.system.2020.102328

Johnson, M. D. (2017). Cognitive task complexity and L2 written syntactic complexity, accuracy, lexical complexity, and fluency: A research synthesis and metaanalysis. Journal of Second Language Writing, 37, 13-18.

Kafipour, R., Mahmoudi, E. \& Khojasteh, L. (2018). The effect of task-based language teaching on analytic writing in EFL classrooms. Cogent Education 5 (1). https://doi.org/10.1080/2331186X.2018.1496627

Kormos, J. (2011). Task complexity and linguistic and discourse features of narrative writing performance. Journal of Second Language Writing 20 (2011), 148-161. http://doi.org/10.1016/j.jslw.2011.02.001

Kuiken, F. \&Vedder, I. (2007). Task complexity and measures of linguistic performance in L2 writing. International Review of Applied Linguistics in Language Teaching, $45,261-284$.

Lee, J. (2020). Task closure and task complexity effects on L2 written performance. Journal of Second Language Writing $50 \quad$ (2020), 100777. http://doi.org/10.1016/j.jslw.2020.100777

Marashi, H. \& Mirghafari, S. (2019). Using Content-Based and Task-Based teaching in a critical setting to improve EFL learners' writing. Studies in English Language and Education, 6(1), 26-43. http://doi.org/10.24815/siele.v6i1.11745

Norris, J. M., Ortega, L. (Eds.). (2006). Synthesizing research on language learning and teaching. John Benjamins Publishing Company.

Nunan, D. (2004). Task-based language teaching. Cambridge University Press. 
Parvizi, G., Khoshsima, H. \& Tajik, M. (2016). The impact of task-based language teaching on Iranian female intermediate EFL learners' writing performance. International journal of learning and development 6 (4). http://dx.doi.org/10.5296/ijld.v6i4.10341

Rajabi, B. \& Hashemian, M. (2015). TBLT or technology: Which is effective to teach resumptive pronouns in writing? Procedia-Social and Behavioral Sciences 192 (2015), 321-326. http://doi.org/10.1016/j.sbspro.2015.06.046

Robinson, P. (2001). Task complexity, task difficulty, and task production: Exploring interactions in a componential framework. Applied Linguistics, 22, 27-57.

Sari, A., Kaharuddin, A. \& Jabal An Nur, M. (2020). Task-based language teaching in the classroom: An effort to teach students' skills in writing descriptive text. $2^{\text {nd }}$ International conference on English Language Education (ICONELE) 2020.

Sari. N.N.R., Tantra, D.K. \& Santosa, M. H. (2018). Task-based language teaching and text types in teaching writing using communicative approach. SHS Web of conferences 42, 00064 (2018). https://doi.org/10.1051/shsconf/20184200064

Shajeri, E. \& Izadpanah, S. (2016). The impact of task complexity along single task dimension on Iranian EFL learners' writing production. Theory and Practice in Language Studies 6 (5), 935-945. http://dx.doi.org/10.17507/tpls.0605.04

Skehan, P. (1998). A cognitive approach to language learning. Oxford. Oxford University Press.

Tabari, M. A. (2021). Task preparedness and L2 written production: Investigating effects of planning modes on L2 learners' focus of attention and output. Journal of Second Language Writing $52 \quad$ (2021), 100814. http://doi.org/10.1016/j.jslw.2021.100814

Vasylets, O., Gilabert, R. \& Manchon, R. (2017). The effects of mode and task complexity on second language production. Language Learning 67(2), 394-430. http://doi.org/10.1111/lang.12228

Zhan, J. \& Ong, J. (2010). Effects of task complexity on the fluency and lexical complexity in EFL students' argumentative writing. Journal of Second Language Writing 19 (2010), 218-233. http://doi.org/10.1016/j.jslw.2010.10.003

Zhan, J., Sun, Q. \& Zhan, L. (2021). Effects of manipulating writing task complexity on learners' performance in completing vocabulary and syntactic tasks. Language Teaching Research (2021),1-22 -. http://doi.org/10.1177/13621688211024360

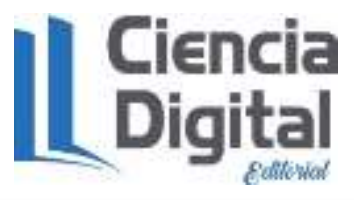


El artículo que se publica es de exclusiva responsabilidad de los autores y no necesariamente reflejan el pensamiento de la Revista Ciencia Digital.

\section{LCiencia}

El artículo queda en propiedad de la revista y, por tanto, su publicación parcial y/o total en otro medio tiene que ser autorizado por el director de la Revista Ciencia Digital.
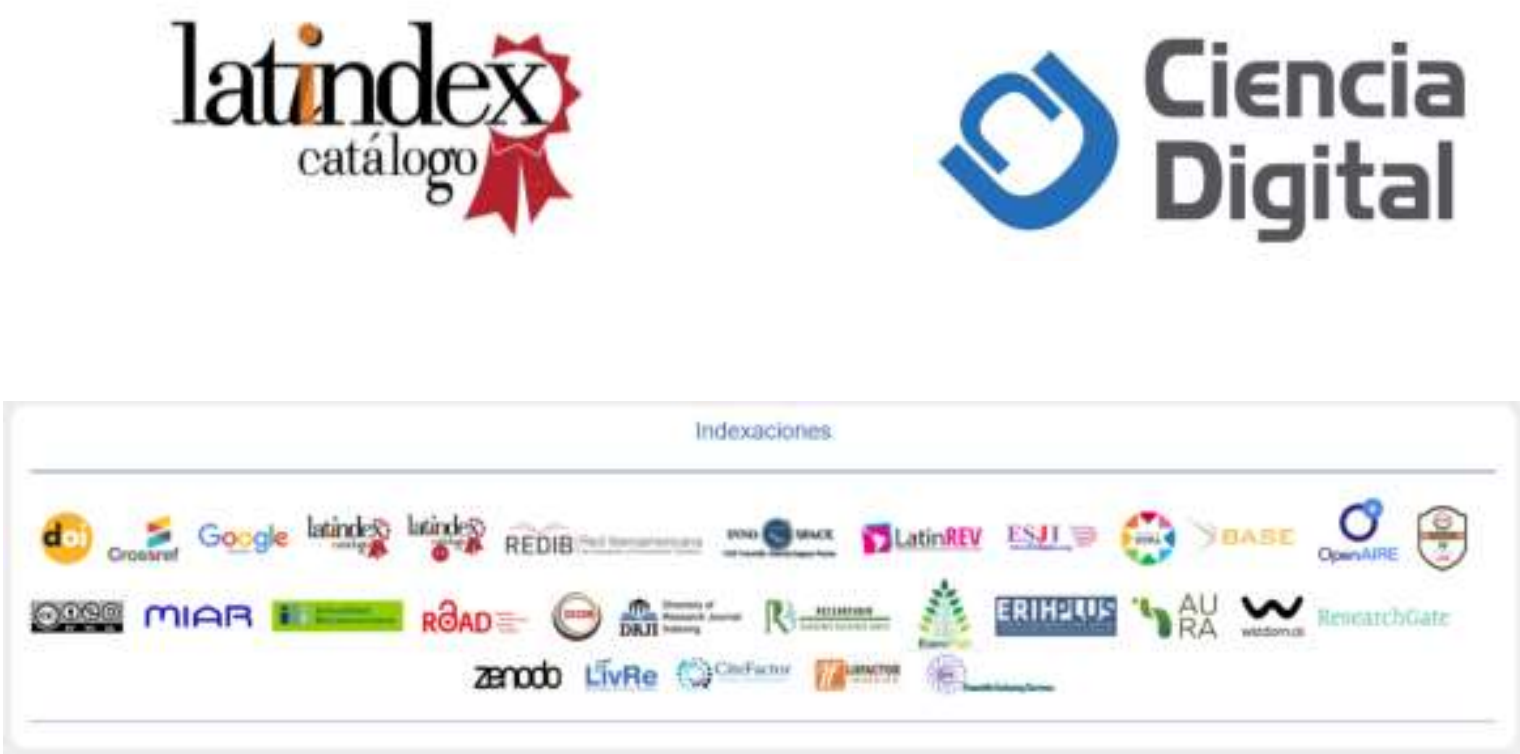